\title{
The role of the WNT/ $\beta$-catenin pathway in central nervous system primitive neuroectodermal tumours (CNS PNETs)
}

\author{
H A Rogers ${ }^{*}, 1, \mathrm{~J} \mathrm{H} \mathrm{Ward}^{1}$, S Miller ${ }^{1}$, J Lowe ${ }^{2}$, B Coyle ${ }^{1}$ and R G Grundy ${ }^{1}$ \\ ${ }^{1}$ Children's Brain Tumour Research Centre, Department of Clinical Sciences, D Floor Medical School, Queen's Medical Centre, \\ University of Nottingham, Nottingham NG7 2UH, UK and 'School of Molecular Medical Sciences, Medical School, Queen's \\ Medical Centre, University of Nottingham, Nottingham NG7 2UH, UK
}

Background: Central nervous system primitive neuroectodermal tumours (CNS PNETs) are embryonal tumours occurring predominantly in children. Current lack of knowledge regarding their underlying biology hinders development of more effective treatments. We previously identified WNT/ $\beta$-catenin pathway activation in one-third of CNS PNETs, which was potentially linked to a better prognosis. In this study, we have extended our cohort, achieving a statistically significant correlation with prognosis. We additionally investigated the biological effects of WNT/ $\beta$-catenin pathway activation in tumour pathogenesis.

Methods: A total of 42 primary and 8 recurrent CNS PNETs were analysed for WNT/ $\beta$-catenin pathway status using $\beta$-catenin immunohistochemistry. Genomic copy number and mRNA expression data were analysed to identify a molecular profile linked to WNT/ $\beta$-catenin pathway activation.

Results: Pathway activation was seen in $26 \%$ of CNS PNETs and was significantly associated with longer overall survival. Genes displaying a significant difference in expression levels, between tumours with and without WNT/ $\beta$-catenin pathway activation, included several involved in normal CNS development suggesting aberrant pathway activation may be disrupting this process.

Conclusion: We have identified WNT/ $\beta$-catenin pathway status as a marker, which could potentially be used to stratify disease risk for patients with CNS PNET. Gene expression data suggest pathway activation is disrupting normal differentiation in the CNS.

Central nervous system tumours are the most common solid tumours during childhood. Central nervous system primitive neuroectodermal tumours (CNS PNETs) are high-grade embryonal tumours that occur at any extracerebellar site in the CNS and are composed of undifferentiated or poorly differentiated neuroepithelial cells (Louis et al, 2007). Currently, outcome for children with CNS PNET is poor with a 5-year survival rate of $31-53 \%$ (Reddy et al, 2000; Geyer et al, 2005). Pineoblastomas are highly malignant PNETs of the pineal gland, which histologically resemble other PNETs of the CNS (Louis et al, 2007). In the United Kingdom, pineoblastomas are treated with protocols similar to CNS PNETs (Pizer et al, 2006).
Relatively little research has been undertaken to elucidate the molecular basis of CNS PNETs. Previously they have been grouped with the histologically similar tumour medulloblastoma; both being composed of poorly differentiated round 'small blue' cells with scant cytoplasm (Louis et al, 2007). Currently, CNS PNETS are treated with therapy designed for high-risk medulloblastoma (Li et al, 2005). However, several studies suggest this approach is less effective in CNS PNET than medulloblastoma (Paulino and Melian, 1999; Reddy et al, 2000; Hong et al, 2004). Recent research has suggested there are molecular and genetic differences between CNS PNET and medulloblastoma (Pomeroy et al, 2002; Inda et al, 2005; McCabe et al, 2006; Pfister et al, 2007a).

*Correspondence: Dr H A Rogers; E-mail: hazel.rogers@nottingham.ac.uk

Received 9 January 2013; revised 22 March 2013; accepted 24 March 2013;

published onlne 16 April 2013

(c) 2013 Cancer Research UK. All rights reserved 0007-0920/13

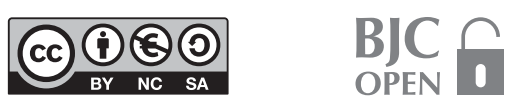


An increased understanding of the molecular genetic basis of CNS PNET is therefore needed and will allow a more targeted approach to therapy. Recent research has started to elucidate the biological and genetic characteristics of CNS PNET and identify molecular subgroups (Miller et al, 2011; Picard et al, 2012). We previously published a study showing approximately one-third of supratentorially located CNS PNETs displayed $\mathrm{WNT} / \beta$-catenin pathway activation, which was potentially associated with a better prognosis (Rogers et al, 2009). The $\mathrm{WNT} / \beta$-catenin pathway has been found to be aberrantly activated in a number of cancers including medulloblastoma (Ellison et al, 2005; Thompson et al, 2006; Kool et al, 2008; Northcott et al, 2010). The pathway has a role in many cellular functions including proliferation, differentiation and migration. When the pathway is inactive, the downstream effector $\beta$-catenin is bound to a cytoplasmic complex, which phosphorylates it targeting the protein for degradation. When a WNT ligand binds to its receptor the pathway is activated leading to the destabilisation of the cytoplasmic complex, preventing phosphorylation of $\beta$-catenin and allowing translocation to the nucleus where it acts as a transcriptional co-activator (Morin, 1999).

In this study, we aimed to confirm the link between WNT/ $\beta$-catenin pathway activation and prognosis in supratentorially located CNS PNET and additionally investigate the biological effects of pathway activation. We have extended our cohort of supratentorially located CNS PNETs analysed for $\mathrm{WNT} / \beta$-catenin pathway status using $\beta$-catenin immunohistochemistry (IHC), through which we demonstrated a significant link with a better survival. In addition, we utilised previously published genomic copy number and mRNA expression array data to identify a molecular profile linked to CNS PNETs with $\mathrm{WNT} / \beta$-catenin pathway activation (Li et al, 2009; Miller et al, 2011). Genes involved in development of the CNS were identified suggesting this process may be disrupted in the tumours through aberrant pathway activation. Central nervous system primitive neuroectodermal tumours with pathway activation displayed lower levels of markers of neuronal differentiation compared with other tumours supporting this hypothesis.

\section{MATERIALS AND METHODS}

Sample information. Tumour samples were obtained from the Children's Cancer and Leukaemia Group (CCLG) and the Cooperative Human Tissue Network (CHTN). Twelve snap-frozen supratentorially located CNS PNETs and one pineoblastoma were obtained. Three CNS PNETs were recurrences, one with the paired primary included in the study. Ten of the CNS PNETs and the one pineoblastoma were run on Affymetrix U133 plus 2 arrays (Affymetrix, Santa Clara, CA, USA). Ten CNS PNETs were used for qPCR analysis, eight of which were also run on the arrays.

Fifty retrospective supratentorial CNS PNETs and nine pineoblastomas were obtained as paraffin-embedded blocks following formalin fixation. Seven CNS PNETs were recurrences. For six the paired primary was also included in the study. For one patient, a tumour sample was obtained from a second surgery (1 week later). Twenty-three of the primary and seven recurrent CNS PNETs plus five primary pineoblastomas were originally analysed in a previous study (Rogers et al, 2009). In this study, an additional 19 primary and 2 recurrent CNS PNETs, plus 4 primary pineoblastomas were added to the cohort. Samples were analysed using whole sections or on a tissue microarray (TMA). For TMAs, following diagnostic pathology review representative areas of tumour tissue were selected. Three cores from each tumour were included.

Clinical information was obtained from CCLG, CHTN and local centres. Multiple Centre Research Ethics Committee (MREC, 04/ MRE04/72) approval was obtained. Consent for use of tumour samples was taken in accordance with national tumour banking procedures and the Human Tissue Act. Work was conducted in premises licensed under the Human Tissue Act.

Immunohistochemistry. Immunohistochemistry was carried out on TMAs and whole sections as described previously (Ridley et al, 2008). Slides were incubated with $\beta$-catenin ( 1 in 500, Cell Signaling Technology, Danvers, MA, USA), map2 (1 in 200, Abcam, Cambridge, UK) and synaptophysin (1 in 200, Dako, Ely, UK). $\beta$-Catenin data from our previous study were used in our analysis (Rogers et al, 2009). Immunohistochemistry was carried out for an additional 23 samples, 19 CNS PNET and 4 pineoblastoma, as previously described (Rogers et al, 2009). Briefly, $\beta$-catenin was scored as nuclear or non-nuclear. The nuclear stained samples were divided into two groups defined by the percentage of positive nuclei. Samples with $<10 \%$ of nuclei positive were labelled as 'low' and $>10 \%$ as 'high'. Map2 was scored as positive or negative. Positive samples were split into two groups showing high and low intensity staining. Synaptophysin was scored as positive or negative.

Overall, and progression-free, survival were investigated using the Kaplan-Meier method. The differences were estimated using the log-rank (Mantel-Cox) test. Overall survival (OS) was defined as the time between date of original diagnosis and date of death. Progression-free survival (PFS) was defined as the time between date of original diagnosis and date of first event (recurrence or death). Patients still alive at the end of the study were censored at the date of last follow-up.

RNA extraction. A small piece of tissue was prepared on a glass slide as a diagnostic smear with subsequent H\&E staining. Slides were reviewed by a pathologist to determine if tumour cells were present.

Total RNA was extracted from 12 CNS PNET and 1 pineoblastoma frozen tumour samples. In all, $40-50 \mathrm{mg}$ of tissue was used for extraction using the mirVana miRNA Isolation kit (Invitrogen, Carlsbad, CA, USA). For cell culture experiments, RNA was extracted from harvested cells using RNA STAT60 (Amsbio, Abingdon, UK) following the manufacturer's instructions. After extraction, RNA was treated with DNAse (Promega, Madison, WI, USA; $12 \mu$ ) at $37^{\circ} \mathrm{C}$ for 30 min. RNA quantity and quality was measured using a Nanodrop ND1000 spectrophotometer (Nanodrop, Wilmington, DE, USA) and an Agilent 2100 Bioanalyser (Agilent Technologies, Santa Clara, CA, USA).

Gene expression microarray analysis. RNA from 10 CNS PNETs and 1 pineoblastoma were run on Affymetrix U133 plus 2.0 arrays. Three CNS PNETs were recurrences, 1 paired, plus 1 second surgery sample. Arrays were run by the NASC Affymetrix service (National Arabidopsis Stock Centre, University of Nottingham, Nottingham, UK) according to the manufacturer's recommendations (Affymetrix).

Raw data were processed using the robust multiarray average algorithm using Expression Console software (Affymetrix). Hierarchical clustering was performed in Spotfire DecisionSite for Functional Genomics (TIBCO Software Inc, Palo Alto, CA, USA). Euclidean distance measure and weighted pair-group average clustering method were used. Principal component analysis (PCA) and class comparisons were performed in GeneSpringGX 11.2 (Agilent Technologies). Genes differentially expressed between subgroups were identified using a $t$-test with a Benjamini and Hochberg multiple test correction (Benjamini and Hochberg, $1995)$. Genes with a $P$-value $<0.05$ were considered significant.

Microarray data from this study are available at NCBI Gene Expression Omnibus (http:/www.ncbi.nlm.nih.gov/geo/) under the accession number GSE19404.

Quantitative PCR. cDNA synthesis was carried out using the Revertaid cDNA synthesis kit (Fermentas, St Leon-Rot, Germany) using 500 ng RNA. A control was included for each sample where 
reverse transcriptase was excluded from the reaction mix to test for genomic DNA contamination in subsequent PCR reactions.

PCR reactions were carried as previously described (Rogers et al, 2012a). Primer sequences and annealing temperatures are displayed in Table 1. Data were normalised using GAPDH. Each cDNA sample was analysed in triplicate. Primer efficiency and precision were calculated using a standard curve. Relative expression to a calibrator sample was calculated using the Pfaffl equation (Pfaffl, 2001). For tumour samples, temporal lobe RNA (BioChain, Newark, CA, USA) was used as a calibrator.

Cell culture. PFSK1 cells were obtained from the American Type Culture Collection (ATCC, Teddington, UK). Cells were cultured in standard humidified incubators at $5 \% \mathrm{CO}_{2}$ in RPMI-1640 medium (Invitrogen) supplemented with $15 \%$ fetal bovine serum (PAA Laboratories, Pasching, Austria) and antibiotics. For experiments, cells were seeded in 24-well plates and incubated overnight. The following day cells were treated with recombinant wnt3a protein at $100 \mathrm{ng} \mathrm{ml}^{-1}$ (R\&D Systems, Abingdon, UK) or vehicle (PBS, 0.1\% BSA). At specified time points, cells were harvested for RNA extraction.

Immunofluorescence. Cells were seeded in chamber slides. The following day cells were treated with recombinant wnt3a protein at $100 \mathrm{ng} \mathrm{ml}^{-1}$ (R\&D Systems) or vehicle (PBS, 0.1\% BSA). After $24 \mathrm{~h}$, cells were fixed by incubating with $4 \%$ PFA for $20 \mathrm{~min}$. Immuno-

Table 1. Primer sequences

\begin{tabular}{|l|l|l|l|}
\hline Gene name & Forward primer sequence $\left(\mathbf{5}^{\prime} \mathbf{- 3}^{\prime}\right)$ & Reverse primer sequence $\left(\mathbf{5}^{\prime}-\mathbf{3}^{\prime}\right)$ & Annealing temperature \\
\hline LEF1 & AAGCCCAGCACTTGAATTGT & ATGACAGTTTTGGCAAAGG & $62^{\circ} \mathrm{C}$ \\
\hline ZIC2 & CTAATCTCCATGCCCACGTT & GAACGCAATCCGGAGTTTTA & $59^{\circ} \mathrm{C}$ \\
\hline MSX1 & GAACGCAATCCGGAGTTTTA & CAGGAGACATGGCCTCTAGC & $63^{\circ} \mathrm{C}$ \\
\hline PLXNB2 & TACGATGCCTTCCTGACCTC & TCTTGGAACTGCTCCCAGTC & $61^{\circ} \mathrm{C}$ \\
\hline AXIN2 & TGCTTTCGTGGAAATGACAG & AGGTGTGTGGAGGAAAGGTG & $61^{\circ} \mathrm{C}$ \\
\hline GAPDH & ATGTTCGTCATGGGTGTGAA & GTCTTCTGGGTGGCAGTGAT & $59-63^{\circ} \mathrm{C}$ \\
\hline
\end{tabular}

A

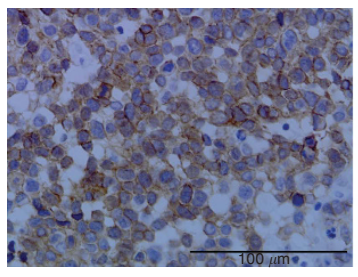

D

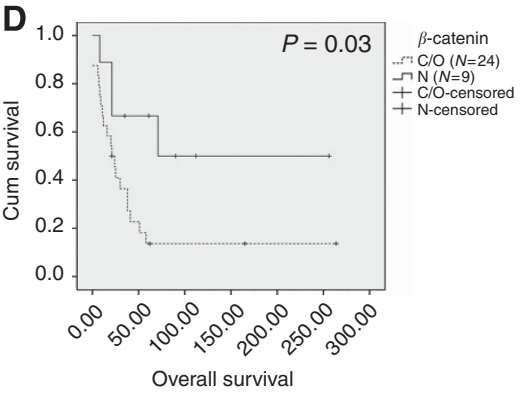

$\mathbf{F}$

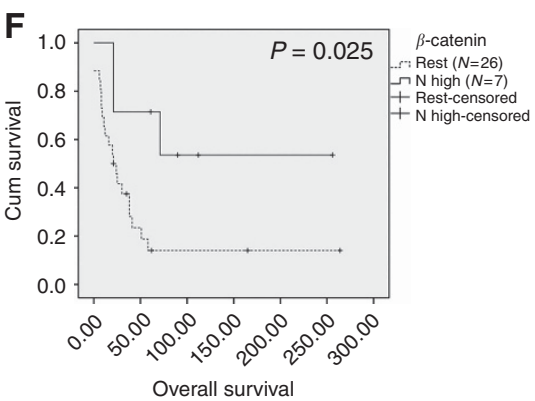

B

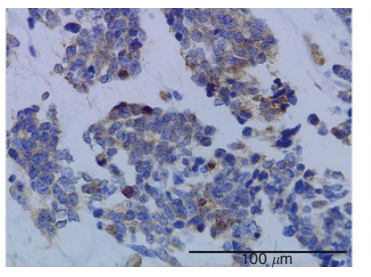

C

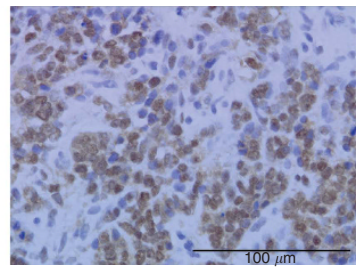

E

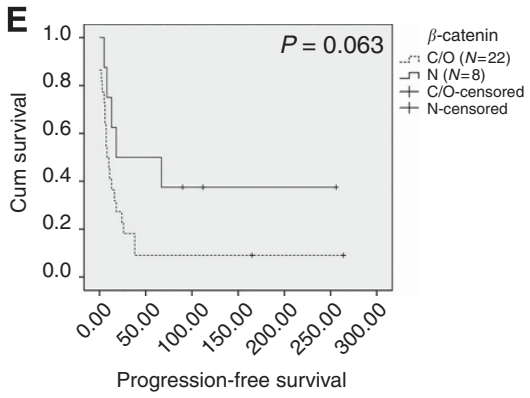

G

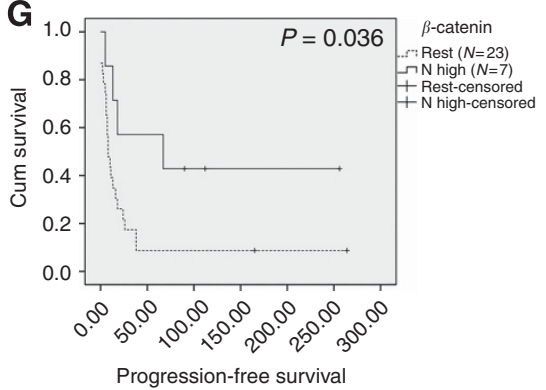

Figure 1. $\beta$-Catenin immunohistochemistry displayed different patterns of staining in different tumours; cytoplasmic (A), low nuclear $(<10 \%$ nuclei) (B) or high nuclear ( $>10 \%$ nuclei) (C). A significant association was seen between WNT/ $\beta$-catenin pathway activation and a better OS for CNS PNETs ( $D$-OS $P=0.030$ ). An association just below significance was seen for PFS (E-PFS $P=0.063$ ). Pathway activation was predicted by $\beta$-catenin nuclear staining $(\mathrm{N})$ compared with cytoplasmic or negative staining (C/O). A significant association was also found with OS and PFS when the CNS PNETs displaying high nuclear staining ( $N$ high) were compared with the rest of the CNS PNET cohort (Rest) ( $F-O S P=0.025$, G-PFS $P=0.036$ ). 
fluorescence was carried out as previously described (Rogers et al, 2012b). Briefly, after blocking in 5\% normal goat serum (Invitrogen) and $0.25 \%$ Triton X-100 (Sigma-Aldrich, Poole, UK) for $1 \mathrm{~h}$ at room temperature, cells were incubated with mouse anti- $\beta$-catenin primary antibody at $4{ }^{\circ} \mathrm{C}$ overnight ( 1 in 200,2677 Cell Signaling Technology). For signal detection, cells were incubated with Alexa Fluor 555 goat anti-mouse secondary antibody (1 in 500, Invitrogen) at room temperature for $1 \mathrm{~h}$, then mounted using Vectashield containing 4', 6-diamidinophenylindole (Vector Laboratories, Peterborough, UK). Images were obtained using a Leica DMRM fluorescent microscope (Nikon, Digital sight-USB (H), Kingstonupon-Thames, UK) equipped with a Nikon digital camera. NIS elements software was used to capture images (Nikon).

Copy number analysis. Previously published 100K SNP array data were used to analyse DNA copy number changes (GEO accession number GSE12370; Miller et al, 2011). Affymetrix CEL files were imported into Genespring GX11.2 (Agilent Technologies). Tumour data were either normalised using matched constitutional DNA (available for 7 samples) or the 270 HAPMAP samples (The International HapMap Consortium, 2003). GISTIC analysis was performed using Genespring GX11.2. Regions with a $q$-value $<0.25$ were deemed significant.

\section{RESULTS}

We have analysed WNT/ $\beta$-catenin pathway status using $\beta$-catenin IHC for additional CNS PNETs to add to our previously published cohort (Rogers et al, 2009). Our original study contained 23 primary CNS PNETs plus 5 pineoblastomas. We have almost doubled the size of our cohort, adding 19 primary CNS PNETs and 4 pineoblastomas. We used nuclear localisation of $\beta$-catenin to define $\mathrm{WNT} / \beta$-catenin pathway activation. Nuclear localisation was seen in 11 of the 42 primary CNS PNETs (26\%), 8 displaying high staining and 3 low (Figures 1A-C). Eight CNS PNET recurrences were analysed in total (two new samples). Four displayed high and two low nuclear staining. Two pineoblastomas (22\%) displayed low nuclear staining.

Clinical information was available for 33 CNS PNET samples for OS analysis and 30 samples for PFS. A significant association between $\beta$-catenin nuclear staining and a better OS was identified in the CNS PNET cohort $(P=0.03)$. An association just below significance was found with PFS $(P=0.063)$. A slightly higher significance was obtained for the CNS PNET cohort if the high nuclear group was analysed against the rest of the cohort (OS $P=0.025$, PFS $P=0.036$; Figures $1 \mathrm{D}-\mathrm{G})$. The median survival for the CNS PNETs with $\beta$-catenin nuclear staining was 252 months with a 5 -year survival rate of $52 \%$ compared with a median survival of 24 months and a 5 -year survival rate of $13 \%$ in the rest of the CNS PNETs.

The number of pineoblastomas was too low to carry out a statistical analysis of survival data. However, of the two tumours displaying low nuclear positivity for $\beta$-catenin, one died after 15 months but the other is alive, progression free, after 169 months. The median survival for the six pineoblastomas showing either cytoplasmic or negative $\beta$-catenin staining was 36 months with a 5 -year survival rate of $17 \%$, which is similar to the CNS PNETs displaying this $\beta$-catenin staining pattern.

To understand the biological effects of $\mathrm{WNT} / \beta$-catenin pathway activation, we analysed mRNA expression array data. We initially analysed a published cohort of 33 primary CNS PNETs (GEO accession number GSE14295; Li et al, 2009). As $\beta$-catenin staining had not been carried out on this cohort we used AXIN2 expression to define pathway activation. AXIN2 has previously been shown to be induced by the WNT/ $\beta$-catenin pathway (Jho et al, 2002). Increased AXIN2 gene expression has also been seen in WNT subgroup medulloblastomas (Kool et al, 2008; Northcott et al, 2010). We validated our findings from this cohort using array data generated from a subset of our IHC cohort, for which we could define pathway status using $\beta$-catenin IHC.

Initial analysis of the published cohort of 33 primary CNS PNETs identified seven tumours with high AXIN2 expression (signal value above 3500, Supplementary Figure 1) and therefore with predicted pathway activation. Only three of the tumours with high AXIN2 expression had available survival data. The median survival for these tumours was 72 months with a 5 -year survival rate of $60 \%$, compared with a median survival of 13.2 months and 5 -year survival rate of $9 \%$ in the rest of the cohort $(n=19)$. This suggested the tumours with $\mathrm{WNT} / \beta$-catenin pathway activation had a better prognosis, in agreement with our IHC analysis.

Statistical comparison of the tumours with and without pathway activation identified 86 probes with significantly different expression (Supplementary Table 1). A number of $\mathrm{WNT} / \beta$-catenin pathway genes were identified including AXIN2, WNT3A and $L E F 1$. Analysis of the gene list using ingenuity pathway analysis

Table 2. Summary of the top biological functions identified from IPA for the genes displaying a significant difference in expression between CNS PNETs predicted to have WNT/ $\beta$-catenin pathway activation and the rest of the cohort

\begin{tabular}{|c|c|c|}
\hline Name & $\boldsymbol{P}$-value & $\begin{array}{c}\text { Number of } \\
\text { molecules }\end{array}$ \\
\hline \multicolumn{3}{|l|}{ Diseases and disorders } \\
\hline Dental disease & $\begin{array}{l}1.10 \mathrm{E}-03- \\
1.65 \mathrm{E}-02\end{array}$ & 2 \\
\hline Antimicrobial disease & $\begin{array}{l}3.32 \mathrm{E}-03- \\
3.32 \mathrm{E}-03\end{array}$ & 1 \\
\hline Cancer & $\begin{array}{l}3.32 \mathrm{E}-03- \\
4.67 \mathrm{E}-02\end{array}$ & 20 \\
\hline Cardiovascular disease & $\begin{array}{l}3.32 \mathrm{E}-03- \\
9.92 \mathrm{E}-03\end{array}$ & 2 \\
\hline Developmental disorder & $\begin{array}{l}3.32 \mathrm{E}-03- \\
4.55 \mathrm{E}-02\end{array}$ & 6 \\
\hline \multicolumn{3}{|l|}{ Molecular and cellular functions } \\
\hline Cell cycle & $\begin{array}{l}1.08 \mathrm{E}-05- \\
2.95 \mathrm{E}-02\end{array}$ & 5 \\
\hline Cellular compromise & $\begin{array}{l}2.99 \mathrm{E}-04- \\
3.59 \mathrm{E}-02\end{array}$ & 5 \\
\hline Cellular development & $\begin{array}{l}4.78 \mathrm{E}-04- \\
4.75 \mathrm{E}-02\end{array}$ & 18 \\
\hline Cellular growth and proliferation & $\begin{array}{l}9.59 \mathrm{E}-04- \\
4.87 \mathrm{E}-02\end{array}$ & 17 \\
\hline Cell morphology & $\begin{array}{l}1.98 \mathrm{E}-03- \\
4.23 \mathrm{E}-02\end{array}$ & 4 \\
\hline \multicolumn{3}{|c|}{ Physiological system development and function } \\
\hline $\begin{array}{l}\text { Digestive system development and } \\
\text { function }\end{array}$ & $\begin{array}{l}1.22 \mathrm{E}-06- \\
2.62 \mathrm{E}-02\end{array}$ & 6 \\
\hline Organ development & $\begin{array}{l}1.22 \mathrm{E}-06- \\
3.27 \mathrm{E}-02\end{array}$ & 8 \\
\hline $\begin{array}{l}\text { Haematological system development } \\
\text { and function }\end{array}$ & $\begin{array}{l}1.08 \mathrm{E}-05- \\
4.23 \mathrm{E}-02\end{array}$ & 5 \\
\hline Humoral immune response & $\begin{array}{l}1.08 \mathrm{E}-05- \\
9.59 \mathrm{E}-04\end{array}$ & 2 \\
\hline Tissue development & $\begin{array}{l}8.83 \mathrm{E}-05- \\
4.59 \mathrm{E}-02\end{array}$ & 11 \\
\hline \multicolumn{3}{|c|}{$\begin{array}{l}\text { Abbreviations: CNS PNET }=\text { central nervous system primitive neuroectodermal tumour } \\
\text { IPA = ingenuity pathway analysis. }\end{array}$} \\
\hline
\end{tabular}


revealed significant enrichment for genes involved in cellular proliferation and tissue development. Many of the genes have also been linked to cancer (Table 2).

The enrichment for genes involved in tissue development suggested this process might be affected in the tumour cells. We looked at the expression of neuronal markers using the array data. Although none were identified in the statistical comparisons, a trend for lower expression of markers of neuronal differentiation was seen in the tumours with $\mathrm{WNT} / \beta$-catenin pathway activation (Figures 2A-C).

We analysed the protein expression of the neuronal markers map2 and synaptophysin by IHC. High positive staining for map2 was seen in 16 out of 33 primary CNS PNETs analysed. Low or negative staining was seen in the remaining tumours (Figure 2D, E). None of the CNS PNETs displaying high map2 staining displayed high $\beta$ catenin nuclear staining. Four recurrences were analysed; two displaying high and two low or negative map2 expression. The two tumours displaying high map2 expression displayed cytoplasmic $\beta$-catenin only. Five pineoblastomas were analysed; two displaying high and three low map2 expression. One pineoblastoma, with low map2 staining, displayed low $\beta$-catenin nuclear staining (Table 3).

Positive staining for synaptophysin was seen in 19 out of 39 primary CNS PNETs analysed (Figure $2 \mathrm{~F}$ ). The majority of CNS PNETs with nuclear $\beta$-catenin staining were negative for synaptophysin (60\%). Only 4 out of 19 CNS PNETs that were positive for synaptophysin displayed nuclear staining for $\beta$-catenin (two high and two low nuclear staining). Three out of five recurrences displayed high synaptophysin expression, one of which also displayed high and one low $\beta$-catenin nuclear staining. Only one out of eight pineoblastomas was negative for synaptophysin, which was one of two tumours displaying nuclear positivity for $\beta$-catenin (Table 3).

To confirm the gene list identified from the expression data published by Li et al (2009) was associated with WNT/ $\beta$-catenin pathway status, we looked at the expression of these genes using mRNA expression array data, we generated from 11 tumours and we analysed it in our IHC cohort for which RNA was available. All tumours had predicted WNT/ $\beta$-catenin pathway status from $\beta$ catenin IHC analysis, three with nuclear staining (active) and eight without nuclear staining (inactive). We grouped the tumours using the gene list identified from Li et al's data, using hierarchical clustering and PCA. The tumours segregated into two groups according to $\beta$-catenin status, confirming the gene list was associated with $\mathrm{WNT} / \beta$-catenin pathway activation (Figure 3 ).

Interestingly, one primary and recurrent pair were analysed (CNS PNET 07 and 07R), which did not cluster together. Central nervous system PNET 07 was found in the WNT group and CNS PNET 07R in the non-WNT group. This agrees with the pathway status for the two tumours, defined by $\beta$-catenin IHC, with CNS PNET 07 showing nuclear staining and CNS PNET 07R only cytoplasmic. In addition, in our previous study a mutation in the $\beta$-catenin gene was found in CNS PNET 07 but not CNS PNET 07R (Rogers et al, 2009). These results suggest the primary and recurrent tumours were biologically different.

Four genes from the identified gene list, LEF1, ZIC2, MSX1 and $P L X N B 2$, were validated using $\mathrm{qPCR}$. These genes were linked to the WNT/ $\beta$-catenin pathway and/or CNS development. Each gene displayed a significant correlation between qPCR and array data. High expression was seen in the tumours with $\mathrm{WNT} / \beta$-catenin pathway activation, in agreement with the array data (Figure 4).

To further confirm the association between the identified gene list and WNT/ $\beta$-catenin pathway activation, the CNS PNET cell line PFSK1 was treated with recombinant wnt3a protein to activate the pathway. Without wnt3a treatment, the $\mathrm{WNT} / \beta$-catenin pathway was not active in PFSK1 wells, demonstrated by cytoplasmic localisation of $\beta$-catenin. Nuclear localisation of $\beta$-catenin was only seen after treatment with wnt3a protein (Figure 5A). RT-PCR demonstrated that AXIN2 expression was induced in wnt3a-treated cells but was not expressed in vehicletreated cells (Figure 5B). A significant increase in expression of three genes; MSX1, ZIC2 and PLXNB2, selected from the list associated with $\mathrm{WNT} / \beta$-catenin pathway activation, was seen following wnt3a treatment. This suggests the upregulation of these genes found in CNS PNETs with $\mathrm{WNT} / \beta$-catenin pathway activation was directly induced by the pathway (Figure $5 \mathrm{C}$ ).

We compared the gene list we identified associated with $\mathrm{WNT} / \beta$-catenin pathway activation in CNS PNET with previously published gene lists associated with $\mathrm{WNT} / \beta$-catenin pathway subgroup medulloblastomas (Kool et al, 2008; Northcott et al, 2010). In all, 19 out of the 86 genes on our gene list were also linked to WNT subgroup medulloblastomas (Supplementary Table 2). These included genes in the WNT pathway (AXIN2 and LEF1) and genes linked to brain development (JAG2, LAMA5, EFHD1 and ZIC2).

We additionally analysed CNS PNET genomic copy number data, which we have previously published (Miller et al, 2011), to see
A
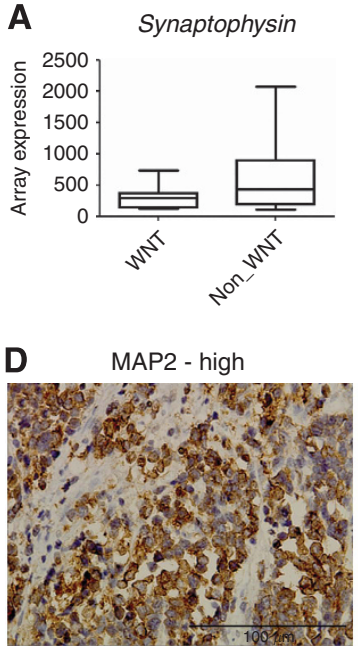
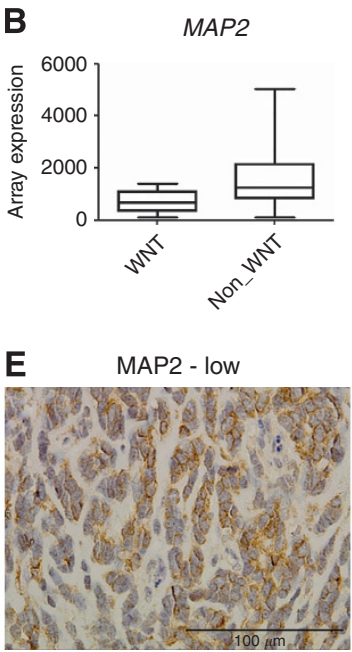
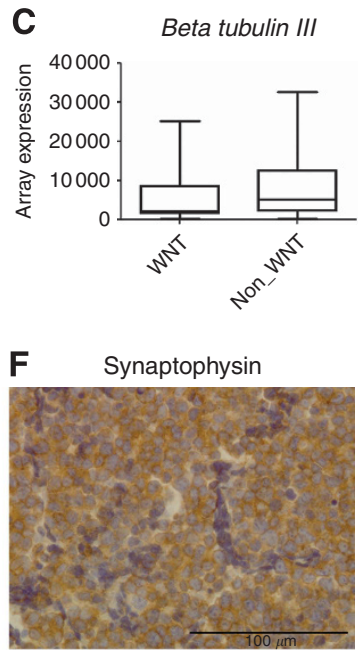

Figure 2. Tumours predicted to have WNT/ $\beta$-catenin pathway activation displayed a lower gene expression level of the neuronal markers synaptophysin (A), MAP2 (B) and $\beta$-tubullin III (C). Expression data were taken from the array data published by Li et al. (2009) (GEO accession number GSE14295). 16 out of 33 CNS PNETs displayed high map2 protein expression (D). The remaining tumours displayed low or negative staining (E). 19 out of 39 CNS PNETs also displayed positive protein staining for synaptophysin (F). 
Table 3. Immunohistochemistry results for $\beta$-catenin, map2 and synaptophysin analysed on CNS PNET and pineoblastoma cohorts

\begin{tabular}{|c|c|c|c|c|}
\hline $\begin{array}{l}\text { Tumour } \\
\text { type }\end{array}$ & $\begin{array}{l}\text { Primary/ } \\
\text { recurrence }\end{array}$ & $\beta$-Catenin & MAP2 & Synaptophysin \\
\hline CNS PNET & Primary & Negative & Negative & Negative \\
\hline CNS PNET & Primary & Negative & $\begin{array}{l}\text { High } \\
\text { positive }\end{array}$ & Positive \\
\hline CNS PNET & Primary & Negative & $\begin{array}{l}\text { High } \\
\text { positive }\end{array}$ & Negative \\
\hline CNS PNET & Primary & Negative & & Positive \\
\hline CNS PNET & Primary & Negative & & Positive \\
\hline CNS PNET & Primary & Cytoplasmic & $\begin{array}{l}\text { High } \\
\text { positive }\end{array}$ & Negative \\
\hline CNS PNET & Primary & Cytoplasmic & Negative & Negative \\
\hline CNS PNET & Primary & Cytoplasmic & $\begin{array}{l}\text { Low } \\
\text { positive }\end{array}$ & Positive \\
\hline CNS PNET & Primary & Cytoplasmic & $\begin{array}{l}\text { Low } \\
\text { positive }\end{array}$ & Positive \\
\hline CNS PNET & Primary & Cytoplasmic & $\begin{array}{l}\text { High } \\
\text { positive }\end{array}$ & Positive \\
\hline CNS PNET & Primary & Cytoplasmic & $\begin{array}{l}\text { Low } \\
\text { positive }\end{array}$ & Negative \\
\hline CNS PNET & Primary & Cytoplasmic & $\begin{array}{l}\text { High } \\
\text { positive }\end{array}$ & Negative \\
\hline CNS PNET & Primary & Cytoplasmic & $\begin{array}{l}\text { Low } \\
\text { positive }\end{array}$ & Negative \\
\hline CNS PNET & Primary & Cytoplasmic & $\begin{array}{l}\text { High } \\
\text { positive }\end{array}$ & Negative \\
\hline CNS PNET & Primary & Cytoplasmic & Negative & Positive \\
\hline CNS PNET & Primary & Cytoplasmic & $\begin{array}{l}\text { High } \\
\text { positive }\end{array}$ & Positive \\
\hline CNS PNET & Primary & Cytoplasmic & $\begin{array}{l}\text { High } \\
\text { positive }\end{array}$ & Positive \\
\hline CNS PNET & Primary & Cytoplasmic & $\begin{array}{l}\text { High } \\
\text { positive }\end{array}$ & Negative \\
\hline CNS PNET & Primary & Cytoplasmic & $\begin{array}{l}\text { High } \\
\text { positive }\end{array}$ & Positive \\
\hline CNS PNET & Primary & Cytoplasmic & $\begin{array}{l}\text { High } \\
\text { positive }\end{array}$ & Positive \\
\hline CNS PNET & Primary & Cytoplasmic & $\begin{array}{l}\text { High } \\
\text { positive }\end{array}$ & Positive \\
\hline CNS PNET & Primary & Cytoplasmic & Negative & Negative \\
\hline CNS PNET & Primary & Cytoplasmic & Negative & Positive \\
\hline CNS PNET & Primary & Cytoplasmic & $\begin{array}{l}\text { High } \\
\text { positive }\end{array}$ & Negative \\
\hline CNS PNET & Primary & Cytoplasmic & $\begin{array}{l}\text { Low } \\
\text { positive }\end{array}$ & \\
\hline CNS PNET & Primary & Cytoplasmic & & Positive \\
\hline CNS PNET & Primary & Cytoplasmic & & Positive \\
\hline CNS PNET & Primary & Cytoplasmic & & Negative \\
\hline CNS PNET & Primary & Cytoplasmic & & Negative \\
\hline CNS PNET & Primary & Cytoplasmic & & Negative \\
\hline CNS PNET & Primary & Low nuclear & Negative & Positive \\
\hline CNS PNET & Primary & Low nuclear & $\begin{array}{l}\text { High } \\
\text { positive }\end{array}$ & Negative \\
\hline CNS PNET & Primary & Low nuclear & $\begin{array}{l}\text { High } \\
\text { positive }\end{array}$ & Positive \\
\hline
\end{tabular}

\begin{tabular}{|c|c|c|c|c|}
\hline $\begin{array}{l}\text { Tumour } \\
\text { type }\end{array}$ & $\begin{array}{l}\text { Primary/ } \\
\text { recurrence }\end{array}$ & $\beta$-Catenin & MAP2 & Synaptophysin \\
\hline CNS PNET & Primary & $\begin{array}{l}\text { High } \\
\text { nuclear }\end{array}$ & Negative & Negative \\
\hline CNS PNET & Primary & $\begin{array}{l}\text { High } \\
\text { nuclear }\end{array}$ & Negative & Negative \\
\hline CNS PNET & Primary & $\begin{array}{l}\text { High } \\
\text { nuclear }\end{array}$ & Negative & Negative \\
\hline CNS PNET & Primary & $\begin{array}{l}\text { High } \\
\text { nuclear }\end{array}$ & $\begin{array}{l}\text { Low } \\
\text { positive }\end{array}$ & Negative \\
\hline CNS PNET & Primary & $\begin{array}{l}\text { High } \\
\text { nuclear }\end{array}$ & $\begin{array}{l}\text { Low } \\
\text { positive }\end{array}$ & Positive \\
\hline CNS PNET & Primary & $\begin{array}{l}\text { High } \\
\text { nuclear }\end{array}$ & $\begin{array}{l}\text { Low } \\
\text { positive }\end{array}$ & Negative \\
\hline CNS PNET & Primary & $\begin{array}{l}\text { High } \\
\text { nuclear }\end{array}$ & & Positive \\
\hline CNS PNET & Recurrence & Cytoplasmic & $\begin{array}{l}\text { High } \\
\text { positive }\end{array}$ & Negative \\
\hline CNS PNET & Recurrence & Cytoplasmic & $\begin{array}{l}\text { High } \\
\text { positive }\end{array}$ & Positive \\
\hline CNS PNET & Recurrence & Low nuclear & & Positive \\
\hline CNS PNET & Recurrence & $\begin{array}{l}\text { High } \\
\text { nuclear }\end{array}$ & $\begin{array}{l}\text { Low } \\
\text { positive }\end{array}$ & Negative \\
\hline CNS PNET & Recurrence & $\begin{array}{l}\text { High } \\
\text { nuclear }\end{array}$ & Negative & Negative \\
\hline CNS PNET & Recurrence & $\begin{array}{l}\text { High } \\
\text { nuclear }\end{array}$ & & Positive \\
\hline Pineoblastoma & Primary & Negative & $\begin{array}{l}\text { Low } \\
\text { positive }\end{array}$ & Positive \\
\hline Pineoblastoma & Primary & Negative & $\begin{array}{l}\text { High } \\
\text { positive }\end{array}$ & Positive \\
\hline Pineoblastoma & Primary & Cytoplasmic & $\begin{array}{l}\text { Low } \\
\text { positive }\end{array}$ & Positive \\
\hline Pineoblastoma & Primary & Cytoplasmic & $\begin{array}{l}\text { High } \\
\text { positive }\end{array}$ & Positive \\
\hline Pineoblastoma & Primary & Cytoplasmic & & Positive \\
\hline Pineoblastoma & Primary & Cytoplasmic & & Positive \\
\hline Pineoblastoma & Primary & Low nuclear & $\begin{array}{l}\text { Low } \\
\text { positive }\end{array}$ & Negative \\
\hline Pineoblastoma & Primary & Low nuclear & & Positive \\
\hline
\end{tabular}

if specific changes were associated with $\mathrm{WNT} / \beta$-catenin pathway activation. A subset of the tumour samples from Miller et al's study were included in the IHC cohort analysed for $\beta$-catenin. Figure 6 displays an overview of the copy number changes across the genome. Regions of significant gain or loss were identified using GISTIC analysis. An independent analysis was carried out for CNS PNETs with and without $\mathrm{WNT} / \beta$-catenin pathway activation. Only four CNS PNETs with $W N T / \beta$-catenin pathway activation had available copy number data limiting the power of analysis. Copy number data were available for eight CNS PNETs without pathway activation. Very few overlapping regions of gain or loss were identified in tumours with and without pathway activation. The only overlapping regions of significant copy number change were gain of two loci on $2 \mathrm{p}$ and loss of one locus on 11p. Significant regions of copy number gain seen in tumours with WNT/ $\beta$-catenin pathway activation included chromosome 2 and 


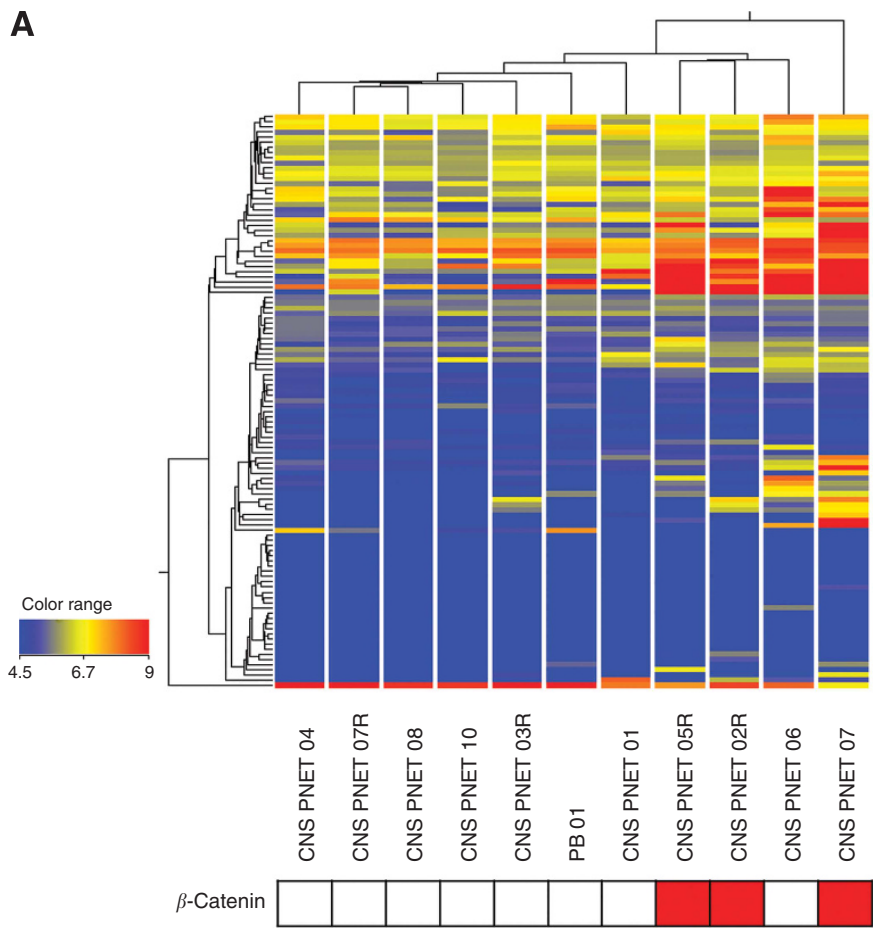

B

Figure 3. Heat map of hierarchical clustering of an independent cohort of tumours confirmed the identified gene list was associated with WNT/ $\beta$-catenin pathway status (A). The gene list identified from the statistical analysis of the expression data published by Li et al (2009) (defined by AXIN2 expression) was used to cluster mRNA expression array data generated from an independent cohort of 11 tumours. The WNT/ $\beta$-catenin pathway status of these 11 tumours was predicted from $\beta$-catenin IHC. The tumours segregated into two groups, represented by the dendogram along the $\mathrm{x}$ axis. All the tumours displaying nuclear $\beta$-catenin staining (red boxes) were found in one cluster group. The dendogram along the $y$ axis represents the clustering of the genes used in the analysis. The same tumour groups found using hierarchical clustering were also identified using PCA (B). The percentage that each principal component contributed to the overall variation is displayed at the end of the three axis. Samples with WNT/ $\beta$-catenin pathway activation are highlighted in red and those without in blue. The red and blue circles highlight the two groups found in the hierarchical clustering, which also segregated together in the PCA analysis, particularly along $x$ axis, representing principal component 1 , which accounted for $50.63 \%$ of the overall variation in the data set. Samples are labelled as CNS PNET and PB (pineoblastoma) followed by a number, which represents an individual patient. An $\mathrm{R}$ indicates a recurrent sample. Primary and recurrent samples with the same case number indicate samples from the same patient.
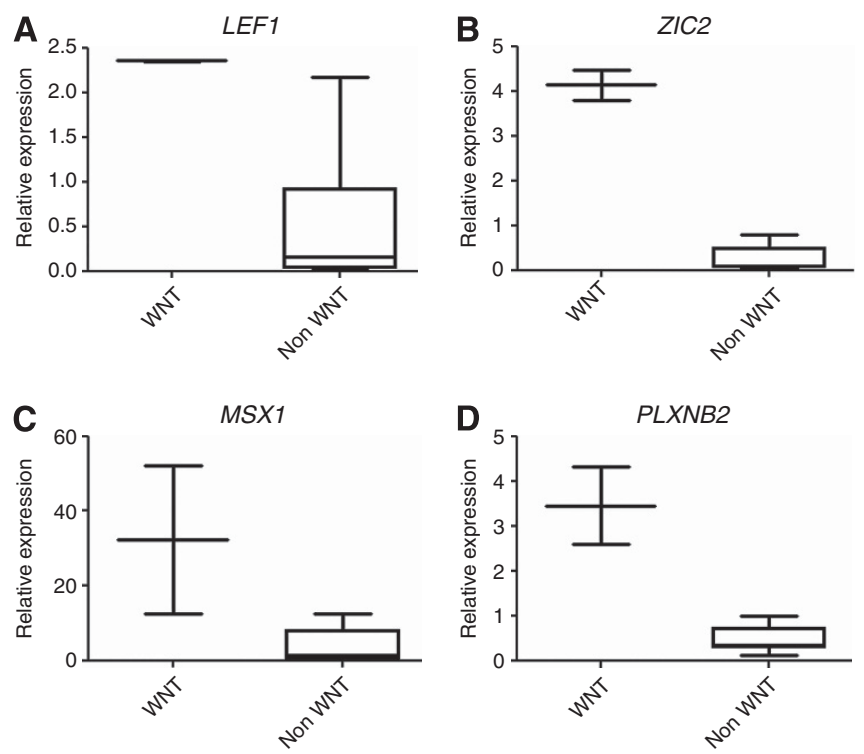

Figure 4. qPCR validation of selected genes; LEF1 (A), ZIC2 (B), MSX1 (C) and PLXNB2 (D). All displayed a significant correlation with mRNA expression array data (LEF1 $r=0.701, P=0.05$; ZIC2 $r=0.775$, $P=0.02 ;$ MSX1 $r=0.822, P=0.01 ; P L X N B 2 r=0.714, P=0.05)$.

A difference between tumours with and without WNT/ $\beta$-catenin pathway activation (defined using $\beta$-catenin $\mathrm{IHC}$ ) was seen for each gene. 12q (Supplementary Table 3). Only one small region of loss on 11 p was significant (Supplementary Table 4). Significant gain was seen on most chromosomes in CNS PNETs without pathway activation. This included gains along chromosomes 5, 7, 9q, 14 and 17 (Supplementary Table 5). Copy number loss was seen on chromosomes 3p, 6p, 9p, 11p, 12q and 16q (Supplementary Table 6).

\section{DISCUSSION}

We have previously published data demonstrating a potential association between $\mathrm{WNT} / \beta$-catenin pathway activation and a better prognosis in CNS PNET. However, the data did not reach significance (Rogers et al, 2009). In this study, we have almost doubled the size of our cohort, which enabled us to identify a significant link to a better prognosis. We additionally identified a gene expression signature linked to pathway activation. This included a number of genes involved in the development of the CNS suggesting pathway activation in the tumours may be disrupting this process.

Our data suggest $\mathrm{WNT} / \beta$-catenin pathway status, measured by $\beta$-catenin IHC, could be used as a prognostic marker for CNS PNETs. The link between pathway activation and a better prognosis has also been identified in medulloblastoma (Ellison et al, 2005; Gajjar et al, 2006; Ellison et al, 2010), where pathway status is now being planned to be used for disease risk stratification in forthcoming medulloblastoma clinical trials (Pizer and Clifford, 

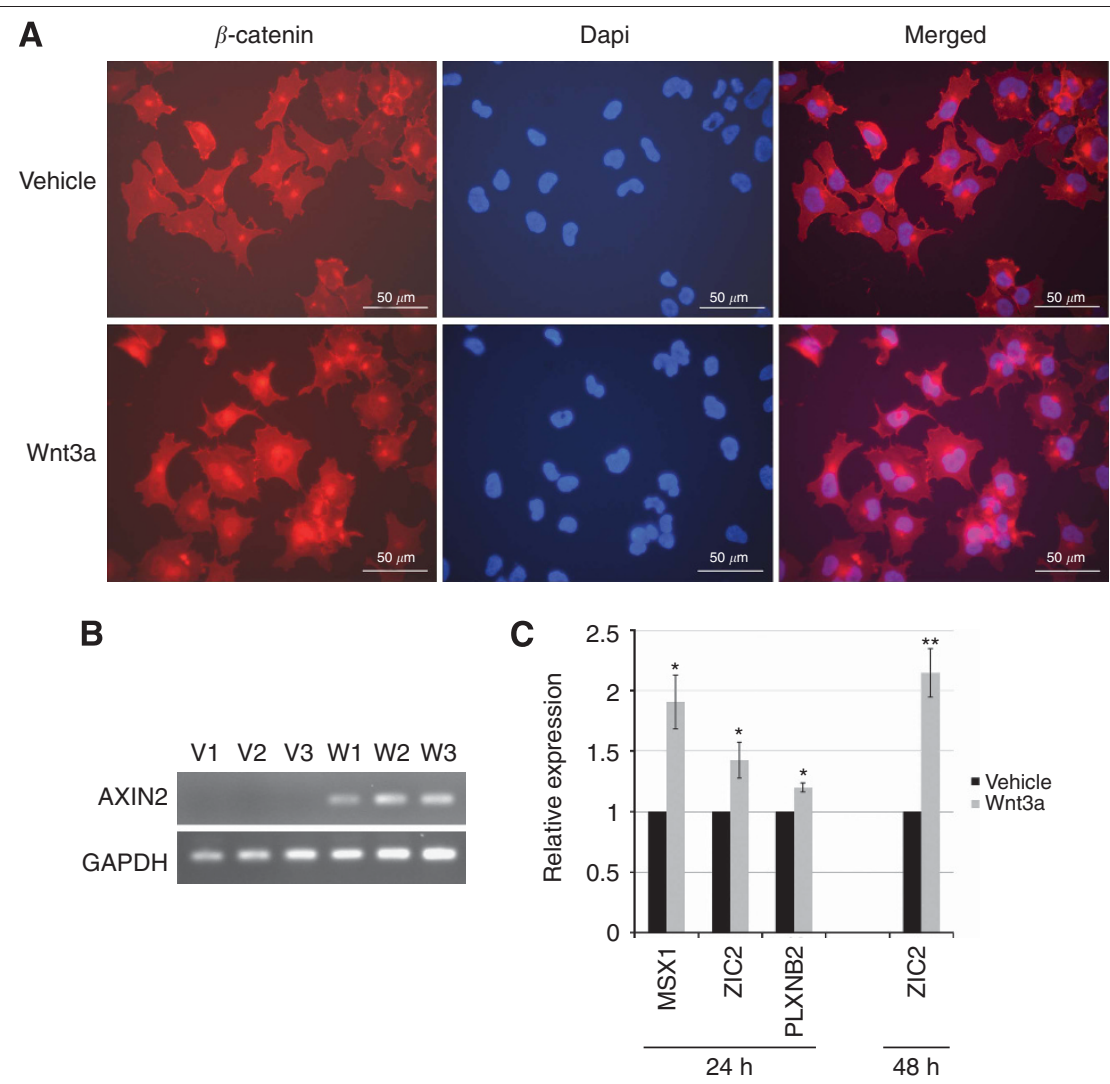

Figure 5. WNT/ $\beta$-catenin pathway activation was induced in PFSK1 cells by treatment with wnt3a recombinant protein $\left(100 \mathrm{ng} \mathrm{ml}{ }^{-1}\right)$. After $24-\mathrm{h}$ pathway activation was seen in the treated cells as indicated by nuclear localisation of $\beta$-catenin (A), measured by immunofluorescence, and induction of AXIN2 expression (B), measured by RT-PCR. A significant increase in expression of MSX1, ZIC2 and PLXNB2 was seen after $24 \mathrm{~h}$, measured by qPCR. For ZIC2, a higher increase in expression was seen after $48 \mathrm{~h}$ (C). Expression in the wnt3a-treated cells is shown relative to the vehicle-treated cells. ${ }^{\star} P<0.05,{ }^{*} P<0.01$.

2009; Ellison et al, 2011). If the association with survival can be confirmed in independent cohorts, pathway status may be able to be used for stratification of CNS PNETs as well. However, the prognosis for medulloblastomas with $\mathrm{WNT} / \beta$-catenin pathway activation is much better than CNS PNET. The 5-year OS rate for CNS PNETs with pathway activation was 52\% compared with medulloblastomas where the WNT subgroup had a 5-year OS rate of 92-95\% (Ellison et al, 2005; Kool et al, 2012). In fact, even medulloblastomas without WNT/ $\beta$-catenin pathway activation had a better 5 -year OS rate (65\%) than WNT CNS PNETs (Ellison et al, 2005).

The association of $\mathrm{WNT} / \beta$-catenin pathway activation with a better prognosis in both CNS PNET and medulloblastoma differs to what has been found in other types of cancer including colon, hepatocellular and breast cancer (Lin et al, 2000; Inagawa et al, 2002; Bondi et al, 2004). This might suggest pathway activation is detrimental to CNS PNET or medulloblastoma survival. However in medulloblastoma, a mouse model of $\mathrm{WNT} / \beta$-catenin pathway activated tumours demonstrated that aberrant pathway activation induced tumour formation suggesting it does have a role in tumour development (Gibson et al, 2010). This may also be the case in CNS PNET. If a pathogenic role can be proven, the WNT/ $\beta$ catenin pathway provides a potential target for future therapies that would be applicable in a quarter of CNS PNET patients.

By utilising gene expression array data published by Li et al (2009), we identified an expression signature linked to WNT/ $\beta$ catenin pathway activation. Analysing the identified gene list in our independent expression array data enabled us to confirm the gene expression signature was linked to pathway activation. A number of genes on the list are involved in CNS development suggesting pathway activation may be affecting this process in the tumours. If the normal developmental process was disrupted, preventing cells from terminally differentiating, cells would remain in a more proliferative state that could lead to tumour development.

The $\mathrm{WNT} / \beta$-catenin pathway has a complex role during development of the CNS. Developmental timing alters the functional impact of pathway activation on cortical neuronal precursor cells (Hirabayashi and Gotoh, 2005). At earlier time points in development, stabilisation of $\beta$-catenin results in expansion of the precursor cell population and enlargement of the cerebral cortex surface area (Chenn and Walsh, 2002; Zechner et al, 2003). However, at later time points pathway activation results in a decreased size of cerebral cortex because of a reduced proliferative progenitor cell pool and increased apoptosis (Ivaniutsin et al, 2009). Neural precursor cells cultured in vitro respond differently to $\mathrm{WNT} / \beta$-catenin signals depending on when, in development, the cells were isolated. Cells isolated earlier in embryonic development show an increase in proliferation in response to WNT signals (Viti et al, 2003; Israsena et al, 2004). Whereas, in those isolated later in development, neuronal differentiation is induced (Hirabayashi et al, 2004; Muroyama et al, 2004).

If the $\mathrm{WNT} / \beta$-catenin pathway was aberrantly activated in neural precursor cells during the earlier phase of embryonic development, neuronal differentiation would be inhibited and the cells would remain in a proliferative state creating more favourable conditions for tumour development. The lower level of gene and protein expression of neuronal markers we demonstrated in CNS PNETs with WNT/ $\beta$-catenin pathway activation compared with those without suggested these tumours show little neuronal 


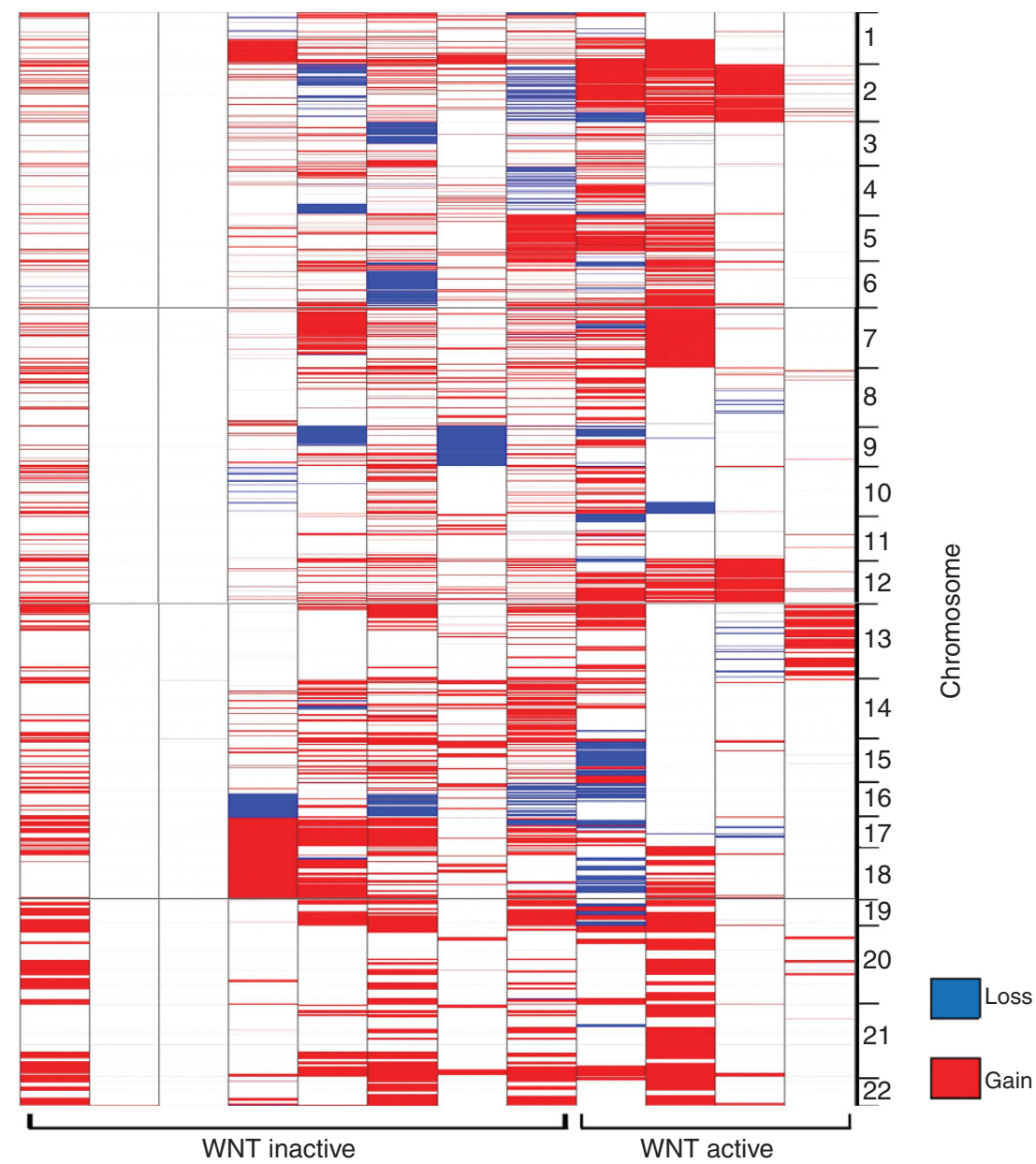

Figure 6. Heatmap visualisation of genome-wide copy number data for 12 primary CNS PNETs with or without WNT/ $\beta$-catenin pathway activation. Pathway activation was determined by $\beta$-catenin IHC where nuclear localisation represented pathway activation. Copy number data were generated using Affymetrix 100K SNP arrays. Each column represents a tumour sample.

differentiation supporting this hypothesis. A similar phenotype has been seen in a mouse model of CNS PNET (Momota et al, 2008). Tumours developed following WNT/ $\beta$-catenin pathway activation in conjunction with Myc expression and p53 knockout. Regions of differentiation were seen in the resulting tumours, but not in cells displaying nuclear $\beta$-catenin. In addition, in a model of WNT subgroup medulloblastoma, WNT/ $\beta$-catenin pathway activation inhibited neuronal differentiation of cells in vitro (Rogers et al, 2012b).

Many of the genes that displayed significantly higher expression in the $\mathrm{WNT} / \beta$-catenin pathway activated tumours encode for proteins with a function in CNS development. MSX1 is a homeobox gene, which is expressed in many different tissues during development including the CNS, where it has a role in neural tube development and inhibition of neuronal differentiation (Liu et al, 2004; Ramos and Robert, 2005). Upregulated expression has been demonstrated after $\mathrm{WNT} / \beta$-catenin pathway activation, including in development and cancer (Willert et al, 2002; Ramos and Robert, 2005; Miller et al, 2007; Revet et al, 2010). ZIC2 is a member of a family of zinc-finger transcription factors, which are involved in early neuronal development and may be involved in maintaining cell pluripotency (Warr et al, 2008; Brown and Brown, 2009; McMahon and Merzdorf, 2010). ZIC2 was downregulated in medulloblastoma compared with normal cerebellum (Pfister et al, 2007b). However, upregulated expression of ZIC2 was found in meningioma (Aruga et al, 2010). PLXNB2 is a member of the plexin family of proteins, which have a role in axon guidance
(Perala et al, 2005). It is expressed in the CNS during embryonic development and has been shown to be expressed by neuroepithelial cells at stages critical in their development (Worzfeld et al, 2004).

A number of the genes that we identified as linked to $\mathrm{WNT} / \beta$ catenin pathway activation in CNS PNET have also been identified in WNT subgroup medulloblastomas (Kool et al, 2008; Northcott et al, 2010), suggesting these genes maybe important to both tumour types. Overlapping genes included some which function in CNS development. JAG2 is a member of the NOTCH pathway, which is known to have important roles during the development of the CNS. NOTCH signalling has been shown to maintain cells in a progenitor state, inhibiting differentiation (de la Pompa et al, 1997; Yun et al, 2002). LAMA5 encodes for the alpha chain of the extracellular matrix protein laminin 5 . Laminins mediate attachment, migration and organisation of cells into tissue during development including development of the CNS (Libby et al, 2000). EFHD1 has been shown to display increased expression during neuronal differentiation (Tominaga and Tomooka, 2002).

Genes involved in embryonic development, many of which have a neuronal-specific function, were also included in the list that did not overlap with genes showing upregulation in WNT subgroup medulloblastoma, including MSX1 and PLXNB2. WNT3A forms part of the WNT/ $\beta$-catenin pathway, which is involved in the control of CNS development. In particular, WNT3A has been shown to be involved in promotion of the expansion of hippocampus progenitor cells (Lee et al, 2000). TLX1 is involved in neuronal fate specification 
(Cheng et al, 2004, 2005; Guillemot et al, 2006), KCTD11 is a marker and regulator of neuronal differentiation (Gallo et al, 2002) and PCP4L1 is expressed in the developing brain including the cerebral cortex (Bulfone et al, 2004).

Through analysis of genomic copy number data from an overlapping cohort of tumours, we were able to identify specific changes significantly enriched for in $\mathrm{WNT} / \beta$-catenin pathway active or inactive CNS PNETs. The number of tumours analysed was relatively low limiting the power of the results. However, very few regions identified overlapped between CNS PNETs with or without pathway activation. Interestingly, a number of the regions identified in the WNT inactive group were previously found by Miller et al (2011). We used a subset of the data from this study in our analysis. Miller et al (2011). identified significant gain of $5 \mathrm{q} 31.3$, which we found to be associated with non-WNT tumours. This region contains genes from the protocadherin gamma family, which have a role in neuronal development (Akins and Biederer, 2006). Miller et al (2011) also identified loss at 9p21.3 and 3p14.2, which we found to be associated with non-WNT tumours in our analysis. The locus lost on 9p21.3 contains the tumour suppressors $C D K N 2 A$ and $B$. In medulloblastoma, WNT active tumours have been associated with chromosome 6 monosomy (Ellison et al, 2011). We did not find this association in CNS PNET.

A recent array-based study of CNS PNETs identified three molecular subgroups (Picard et al, 2012). A proportion of the tumours from Li et al's study, which we analysed, were included in the study by Picard et al. Three out of four tumours that we defined as having WNT/ $\beta$-catenin pathway activation were found in group 3. Only 3 out of 17 tumours we defined as having no pathway activation were found in group 3. This suggests CNS PNETs with $\mathrm{WNT} / \beta$-catenin pathway activation have a biological profile similar to group 3 tumours. The gene expression and clinical profile of group 3 tumours supports this conclusion. MSX1 and ZIC2 both displayed significantly higher gene expression in group 3 tumours. They also displayed downregulation of neural differentiation genes. Genes from the WNT pathway were significantly enriched in group 3 tumours. Group 2 tumours displayed downregulation of the $\mathrm{WNT} / \beta$-catenin pathway and group 1 tumours displayed upregulation of the non-canonical WNT pathway. In addition, group 3 tumours had a better prognosis than other CNS PNETs.

Picard et al also linked genomic copy number changes to the CNS PNET subgroups they identified. 9p21.3 loss, which we saw in non-WNT tumours, was seen in groups 2 and 3.8 p gain, which we saw in non-WNT tumours, was seen by Picard et al in group 2 tumours. Interestingly, Picard et al found chromosome 2 gain to be associated with group 1 tumours. We found chromosome 2 gain to be associated with WNT active tumours, which does not fit with the expression profile of WNT active tumours, which was closer to group 3 tumours. However, gain of chromosome 2 was seen by Picard et al in some group 3 tumours. In addition, we were only able to analyse a small number of tumours limiting the power of analysis and the conclusions we could make.

Pineoblastomas were included in our analysis. These tumours resemble CNS PNETs histologically and are treated on similar protocols (Pizer et al, 2006; Louis et al, 2007). We found two out of nine pineoblastomas displayed $\mathrm{WNT} / \beta$-catenin pathway activation. Very little is known about the pathogenesis of pineoblastomas. Therefore, our results add valuable information and understanding of their underlying tumour biology.

In conclusion, we have demonstrated a significant link between WNT/ $\beta$-catenin pathway activation and a better prognosis in CNS PNET suggesting it is a potential prognostic marker, which could be used to stratify patient disease risk. We have identified an expression signature linked to pathway activation, which contains genes involved in the control of CNS development suggesting aberrant pathway activation in the tumours maybe disrupting this process. If differentiation of progenitor cells is inhibited, cells will remain in a proliferative state creating more favourable conditions for tumour development.

\section{ACKNOWLEDGEMENTS}

This was a Children's Cancer and Leukaemia Group (CCLG) biological study. We acknowledge Dr Lisa Storer and Sarah Leigh Nicholson for their helpful advice and technical support. We thank colleagues in contributing CCLG centres for providing tumour samples and clinical data. CCLG local centres that provided samples included; Nottingham, Birmingham, Great Ormond Street, Cardiff, Liverpool, Cambridge, Royal Marsden Hospital and Bristol. Funding was provided by the Joseph Foote Charitable Trust, the Samantha Dickson Brain Tumour Trust and the Children's Brain Tumour Research Centre.

\section{CONFLICT OF INTEREST}

The authors declare no conflict of interest.

\section{REFERENCES}

Akins MR, Biederer T (2006) Cell-cell interactions in synaptogenesis. Curr Opin Neurobiol 16: 83-89.

Aruga J, Nozaki Y, Hatayama M, Odaka YS, Yokota N (2010) Expression of ZIC family genes in meningiomas and other brain tumors. BMC Cancer 10: 79.

Benjamini Y, Hochberg Y (1995) Controlling the false discovery rate-a practical and powerful approach to multiple testing. J Roy Stat Soc Ser B-Methodological 57: 289-300.

Bondi J, Bukholm G, Nesland JM, Bukholm IR (2004) Expression of nonmembranous beta-catenin and gamma-catenin, c-Myc and cyclin D1 in relation to patient outcome in human colon adenocarcinomas. Apmis 112: 49-56.

Brown L, Brown S (2009) Zic2 is expressed in pluripotent cells in the blastocyst and adult brain expression overlaps with makers of neurogenesis. Gene Expr Patterns 9: 43-49.

Bulfone A, Caccioppoli C, Pardini C, Faedo A, Martinez S, Banfi S (2004) Pcp4l1, a novel gene encoding a Pcp4-like polypeptide, is expressed in specific domains of the developing brain. Gene Expr Patterns 4: 297-301.

Cheng L, Arata A, Mizuguchi R, Qian Y, Karunaratne A, Gray PA, Arata S, Shirasawa S, Bouchard M, Luo P, Chen CL, Busslinger M, Goulding M, Onimaru H, Ma Q (2004) Tlx3 and Tlx1 are post-mitotic selector genes determining glutamatergic over GABAergic cell fates. Nat Neurosci 7: 510-517.

Cheng L, Samad OA, Xu Y, Mizuguchi R, Luo P, Shirasawa S, Goulding M, Ma Q (2005) Lbx1 and Tlx3 are opposing switches in determining GABAergic versus glutamatergic transmitter phenotypes. Nat Neurosci 8 : 1510-1515.

Chenn A, Walsh CA (2002) Regulation of cerebral cortical size by control of cell cycle exit in neural precursors. Science 297: 365-369.

de la Pompa JL, Wakeham A, Correia KM, Samper E, Brown S, Aguilera RJ, Nakano T, Honjo T, Mak TW, Rossant J, Conlon RA (1997) Conservation of the Notch signalling pathway in mammalian neurogenesis. Development 124: $1139-1148$.

Ellison DW, Dalton J, Kocak M, Nicholson SL, Fraga C, Neale G, Kenney AM, Brat DJ, Perry A, Yong WH, Taylor RE, Bailey S, Clifford SC, Gilbertson RJ (2010) Medulloblastoma: clinicopathological correlates of SHH, WNT, and non-SHH/WNT molecular subgroups. Acta Neuropathol 121: 381-396.

Ellison DW, Kocak M, Dalton J, Megahed H, Lusher ME, Ryan SL, Zhao W, Nicholson SL, Taylor RE, Bailey S, Clifford SC (2011) Definition of disease-risk stratification groups in childhood medulloblastoma using combined clinical, pathologic, and molecular variables. J Clin Oncol 29: 1400-1407.

Ellison DW, Onilude OE, Lindsey JC, Lusher ME, Weston CL, Taylor RE, Pearson AD, Clifford SC (2005) Beta-catenin status predicts a favorable 
outcome in childhood medulloblastoma: the United Kingdom Children's Cancer Study Group Brain Tumour Committee. J Clin Oncol 23: 7951-7957.

Gajjar A, Chintagumpala M, Ashley D, Kellie S, Kun LE, Merchant TE, Woo S, Wheeler G, Ahern V, Krasin MJ, Fouladi M, Broniscer A, Krance R, Hale GA, Stewart CF, Dauser R, Sanford RA, Fuller C, Lau C, Boyett JM, Wallace D, Gilbertson RJ (2006) Risk-adapted craniospinal radiotherapy followed by high-dose chemotherapy and stem-cell rescue in children with newly diagnosed medulloblastoma (St Jude Medulloblastoma-96): longterm results from a prospective, multicentre trial. Lancet Oncol 7: 813-820.

Gallo R, Zazzeroni F, Alesse E, Mincione C, Borello U, Buanne P, D’Eugenio R, Mackay AR, Argenti B, Gradini R, Russo MA, Maroder M, Cossu G, Frati L, Screpanti I, Gulino A (2002) REN: a novel, developmentally regulated gene that promotes neural cell differentiation. J Cell Biol 158: 731-740.

Geyer JR, Sposto R, Jennings M, Boyett JM, Axtell RA, Breiger D, Broxson E, Donahue B, Finlay JL, Goldwein JW, Heier LA, Johnson D, Mazewski C, Miller DC, Packer R, Puccetti D, Radcliffe J, Tao ML, Shiminski-Maher T (2005) Multiagent chemotherapy and deferred radiotherapy in infants with malignant brain tumors: a report from the Children's Cancer Group. J Clin Oncol 23: 7621-7631.

Gibson P, Tong Y, Robinson G, Thompson MC, Currle DS, Eden C, Kranenburg TA, Hogg T, Poppleton H, Martin J, Finkelstein D, Pounds S, Weiss A, Patay Z, Scoggins M, Ogg R, Pei Y, Yang ZJ, Brun S, Lee Y, Zindy F, Lindsey JC, Taketo MM, Boop FA, Sanford RA, Gajjar A, Clifford SC, Roussel MF, McKinnon PJ, Gutmann DH, Ellison DW, Wechsler-Reya R, Gilbertson RJ (2010) Subtypes of medulloblastoma have distinct developmental origins. Nature 468: 1095-1099.

Guillemot F, Molnar Z, Tarabykin V, Stoykova A (2006) Molecular mechanisms of cortical differentiation. Eur J Neurosci 23: 857-868.

Hirabayashi Y, Gotoh Y (2005) Stage-dependent fate determination of neural precursor cells in mouse forebrain. Neurosci Res 51: 331-336.

Hirabayashi Y, Itoh Y, Tabata H, Nakajima K, Akiyama T, Masuyama N, Gotoh Y (2004) The Wnt/beta-catenin pathway directs neuronal differentiation of cortical neural precursor cells. Development 131: 2791-2801.

Hong TS, Mehta MP, Boyett JM, Donahue B, Rorke LB, Yao MS, Zeltzer PM (2004) Patterns of failure in supratentorial primitive neuroectodermal tumors treated in Children's Cancer Group Study 921, a phase III combined modality study. Int J Radiat Oncol Biol Phys 60: 204-213.

Inagawa S, Itabashi M, Adachi S, Kawamoto T, Hori M, Shimazaki J, Yoshimi F, Fukao K (2002) Expression and prognostic roles of beta-catenin in hepatocellular carcinoma: correlation with tumor progression and postoperative survival. Clin Cancer Res 8: 450-456.

Inda MM, Perot C, Guillaud-Bataille M, Danglot G, Rey JA, Bello MJ, Fan X, Eberhart C, Zazpe I, Portillo E, Tunon T, Martinez-Penuela JM, Bernheim A, Castresana JS (2005) Genetic heterogeneity in supratentorial and infratentorial primitive neuroectodermal tumours of the central nervous system. Histopathology 47: 631-637.

Israsena N, Hu M, Fu W, Kan L, Kessler JA (2004) The presence of FGF2 signaling determines whether beta-catenin exerts effects on proliferation or neuronal differentiation of neural stem cells. Dev Biol 268: 220-231.

Ivaniutsin U, Chen Y, Mason JO, Price DJ, Pratt T (2009) Adenomatous polyposis coli is required for early events in the normal growth and differentiation of the developing cerebral cortex. Neural Dev 4: 3 .

Jho EH, Zhang T, Domon C, Joo CK, Freund JN, Costantini F (2002) Wnt/ beta-catenin/Tcf signaling induces the transcription of Axin2, a negative regulator of the signaling pathway. Mol Cell Biol 22: 1172-1183.

Kool M, Korshunov A, Remke M, Jones DT, Schlanstein M, Northcott PA, Cho YJ, Koster J, Schouten-van Meeteren A, van Vuurden D, Clifford SC, Pietsch T, von Bueren AO, Rutkowski S, McCabe M, Collins VP, Backlund ML, Haberler C, Bourdeaut F, Delattre O, Doz F, Ellison DW, Gilbertson RJ, Pomeroy SL, Taylor MD, Lichter P, Pfister SM (2012) Molecular subgroups of medulloblastoma: an international meta-analysis of transcriptome, genetic aberrations, and clinical data of WNT, SHH, Group 3, and Group 4 medulloblastomas. Acta Neuropathol 123: 473-484.

Kool M, Koster J, Bunt J, Hasselt NE, Lakeman A, van Sluis P, Troost D, Meeteren NS, Caron HN, Cloos J, Mrsic A, Ylstra B, Grajkowska W, Hartmann W, Pietsch T, Ellison D, Clifford SC, Versteeg R (2008) Integrated genomics identifies five medulloblastoma subtypes with distinct genetic profiles, pathway signatures and clinicopathological features. PLoS One 3: e3088.

Lee SM, Tole S, Grove E, McMahon AP (2000) A local Wnt-3a signal is required for development of the mammalian hippocampus. Development 127: 457-467.
Li M, Lee KF, Lu Y, Clarke I, Shih D, Eberhart C, Collins VP, Van Meter T, Picard D, Zhou L, Boutros PC, Modena P, Liang ML, Scherer SW, Bouffet E, Rutka JT, Pomeroy SL, Lau CC, Taylor MD, Gajjar A, Dirks PB, Hawkins CE, Huang A (2009) Frequent amplification of a chr19q13.41 microRNA polycistron in aggressive primitive neuroectodermal brain tumors. Cancer Cell 16: 533-546.

Li MH, Bouffet E, Hawkins CE, Squire JA, Huang A (2005) Molecular genetics of supratentorial primitive neuroectodermal tumors and pineoblastoma. Neurosurg Focus 19: E3.

Libby RT, Champliaud MF, Claudepierre T, Xu Y, Gibbons EP, Koch M, Burgeson RE, Hunter DD, Brunken WJ (2000) Laminin expression in adult and developing retinae: evidence of two novel CNS laminins J Neurosci 20: 6517-6528.

Lin SY, Xia W, Wang JC, Kwong KY, Spohn B, Wen Y, Pestell RG, Hung MC (2000) Beta-catenin, a novel prognostic marker for breast cancer: its roles in cyclin D1 expression and cancer progression. Proc Natl Acad Sci USA 97: 4262-4266.

Liu Y, Helms AW, Johnson JE (2004) Distinct activities of Msx1 and Msx3 in dorsal neural tube development. Development 131: 1017-1028.

Louis DN, Ohgaki H, Wiestler OD, Cavenee WK, Burger PC, Jouvet A, Scheithauer BW, Kleihues P (2007) The 2007 WHO classification of tumours of the central nervous system. Acta Neuropathol (Berl) 114: 97-109.

McCabe MG, Ichimura K, Liu L, Plant K, Backlund LM, Pearson DM, Collins VP (2006) High-resolution array-based comparative genomic hybridization of medulloblastomas and supratentorial primitive neuroectodermal tumors. J Neuropathol Exp Neurol 65: 549-561.

McMahon AR, Merzdorf CS (2010) Expression of the zic1, zic2, zic3, and zic4 genes in early chick embryos. BMC Res Notes 3: 167.

Miller KA, Barrow J, Collinson JM, Davidson S, Lear M, Hill RE, Mackenzie A (2007) A highly conserved Wnt-dependent TCF4 binding site within the proximal enhancer of the anti-myogenic Msx1 gene supports expression within Pax3-expressing limb bud muscle precursor cells. Dev Biol 311 : 665-678.

Miller S, Rogers HA, Lyon P, Rand V, Adamowicz-Brice M, Clifford SC, Hayden JT, Dyer S, Pfister S, Korshunov A, Brundler MA, Lowe J, Coyle B, Grundy RG (2011) Genome-wide molecular characterization of central nervous system primitive neuroectodermal tumor and pineoblastoma. Neuro Oncol 13: 866-879.

Momota H, Shih AH, Edgar MA, Holland EC (2008) c-Myc and beta-catenin cooperate with loss of p53 to generate multiple members of the primitive neuroectodermal tumor family in mice. Oncogene 27: 4392-4401.

Morin PJ (1999) beta-catenin signaling and cancer. Bioessays 21: 1021-1030.

Muroyama Y, Kondoh H, Takada S (2004) Wnt proteins promote neuronal differentiation in neural stem cell culture. Biochem Biophys Res Commun 313: 915-921.

Northcott PA, Korshunov A, Witt H, Hielscher T, Eberhart CG, Mack S, Bouffet E, Clifford SC, Hawkins CE, French P, Rutka JT, Pfister S, Taylor MD (2010) Medulloblastoma comprises four distinct molecular variants $J$ Clin Oncol 29: 1408-1414.

Paulino AC, Melian E (1999) Medulloblastoma and supratentorial primitive neuroectodermal tumors: an institutional experience. Cancer 86: 142-148.

Perala NM, Immonen T, Sariola H (2005) The expression of plexins during mouse embryogenesis. Gene Expr Patterns 5: 355-362.

Pfaffl MW (2001) A new mathematical model for relative quantification in real-time RT-PCR. Nucleic Acids Res 29: e45.

Pfister S, Remke M, Toedt G, Werft W, Benner A, Mendrzyk F, Wittmann A, Devens F, von Hoff K, Rutkowski S, Kulozik A, Radlwimmer B, Scheurlen W, Lichter P, Korshunov A (2007a) Supratentorial primitive neuroectodermal tumors of the central nervous system frequently harbor deletions of the CDKN2A locus and other genomic aberrations distinct from medulloblastomas. Genes Chromosomes Cancer 46: 839-851.

Pfister S, Schlaeger C, Mendrzyk F, Wittmann A, Benner A, Kulozik A, Scheurlen W, Radlwimmer B, Lichter P (2007b) Array-based profiling of reference-independent methylation status (aPRIMES) identifies frequent promoter methylation and consecutive downregulation of ZIC2 in pediatric medulloblastoma. Nucleic Acids Res 35: e51.

Picard D, Miller S, Hawkins CE, Bouffet E, Rogers HA, Chan TS, Kim SK, Ra YS, Fangusaro J, Korshunov A, Toledano H, Nakamura H, Hayden JT, Chan J, Lafay-Cousin L, Hu P, Fan X, Muraszko KM, Pomeroy SL, Lau CC, Ng HK, Jones C, Van Meter T, Clifford SC, Eberhart C, Gajjar A, Pfister SM, Grundy RG, Huang A (2012) Markers of survival and metastatic potential in childhood CNS primitive neuro-ectodermal brain tumours: an integrative genomic analysis. Lancet Oncol 13: 838-848. 
Pizer BL, Clifford SC (2009) The potential impact of tumour biology on improved clinical practice for medulloblastoma: progress towards biologically driven clinical trials. Br J Neurosurg 23: 364-375.

Pizer BL, Weston CL, Robinson KJ, Ellison DW, Ironside J, Saran F, Lashford LS, Tait D, Lucraft H, Walker DA, Bailey CC, Taylor RE (2006) Analysis of patients with supratentorial primitive neuro-ectodermal tumours entered into the SIOP/UKCCSG PNET 3 study. Eur J Cancer 42: 1120-1128.

Pomeroy SL, Tamayo P, Gaasenbeek M, Sturla LM, Angelo M, McLaughlin ME, Kim JY, Goumnerova LC, Black PM, Lau C, Allen JC, Zagzag D, Olson JM, Curran T, Wetmore C, Biegel JA, Poggio T, Mukherjee S, Rifkin R, Califano A, Stolovitzky G, Louis DN, Mesirov JP, Lander ES, Golub TR (2002) Prediction of central nervous system embryonal tumour outcome based on gene expression. Nature 415: 436-442.

Ramos C, Robert B (2005) msh/Msx gene family in neural development. Trends Genet 21: 624-632.

Reddy AT, Janss AJ, Phillips PC, Weiss HL, Packer RJ (2000) Outcome for children with supratentorial primitive neuroectodermal tumors treated with surgery, radiation, and chemotherapy. Cancer 88: 2189-2193.

Revet I, Huizenga G, Koster J, Volckmann R, van Sluis P, Versteeg R, Geerts D (2010) MSX1 induces the Wnt pathway antagonist genes DKK1, DKK2, DKK3, and SFRP1 in neuroblastoma cells, but does not block Wnt3 and Wnt5A signalling to DVL3. Cancer Lett 289: 195-207.

Ridley L, Rahman R, Brundler MA, Ellison D, Lowe J, Robson K, Prebble E, Luckett I, Gilbertson RJ, Parkes S, Rand V, Coyle B, Grundy RG (2008) Multifactorial analysis of predictors of outcome in pediatric intracranial ependymoma. Neuro Oncol 10: 675-689.

Rogers HA, Kilday JP, Mayne C, Ward J, Adamowicz-Brice M, Schwalbe EC, Clifford SC, Coyle B, Grundy RG (2012a) Supratentorial and spinal pediatric ependymomas display a hypermethylated phenotype which includes the loss of tumor suppressor genes involved in the control of cell growth and death. Acta Neuropathol 123: 711-725.

Rogers HA, Miller S, Lowe J, Brundler MA, Coyle B, Grundy RG (2009) An investigation of WNT pathway activation and association with survival in central nervous system primitive neuroectodermal tumours (CNS PNET). Br J Cancer 100: 1292-1302.

Rogers HA, Sousa S, Salto C, Arenas E, Coyle B, Grundy RG (2012b) WNT/ beta-catenin pathway activation in Myc immortalised cerebellar progenitor cells inhibits neuronal differentiation and generates tumours resembling medulloblastoma. Br J Cancer 107: 1144-1152.
The International HapMap Consortium (2003) The International HapMap Project. Nature 426: 789-796.

Thompson MC, Fuller C, Hogg TL, Dalton J, Finkelstein D, Lau CC, Chintagumpala M, Adesina A, Ashley DM, Kellie SJ, Taylor MD, Curran T, Gajjar A, Gilbertson RJ (2006) Genomics identifies medulloblastoma subgroups that are enriched for specific genetic alterations. J Clin Oncol 24: 1924-1931.

Tominaga M, Tomooka Y (2002) Novel genes cloned from a neuronal cell line newly established from a cerebellum of an adult p53(-/-) mouse. Biochem Biophys Res Commun 297: 473-479.

Viti J, Gulacsi A, Lillien L (2003) Wnt regulation of progenitor maturation in the cortex depends on Shh or fibroblast growth factor 2. J Neurosci 23: 5919-5927.

Warr N, Powles-Glover N, Chappell A, Robson J, Norris D, Arkell RM (2008) Zic2-associated holoprosencephaly is caused by a transient defect in the organizer region during gastrulation. Hum Mol Genet 17: 2986-2996.

Willert J, Epping M, Pollack JR, Brown PO, Nusse R (2002) A transcriptional response to Wnt protein in human embryonic carcinoma cells. BMC Dev Biol 2: 8.

Worzfeld T, Puschel AW, Offermanns S, Kuner R (2004) Plexin-B family members demonstrate non-redundant expression patterns in the developing mouse nervous system: an anatomical basis for morphogenetic effects of Sema4D during development. Eur J Neurosci 19: 2622-2632.

Yun K, Fischman S, Johnson J, Hrabe de Angelis M, Weinmaster G, Rubenstein JL (2002) Modulation of the notch signaling by Mash1 and Dlx $1 / 2$ regulates sequential specification and differentiation of progenitor cell types in the subcortical telencephalon. Development 129: 5029-5040.

Zechner D, Fujita Y, Hulsken J, Muller T, Walther I, Taketo MM, Crenshaw 3rd EB, Birchmeier W, Birchmeier C (2003) beta-Catenin signals regulate cell growth and the balance between progenitor cell expansion and differentiation in the nervous system. Dev Biol 258: 406-418.

Supplementary Information accompanies this paper on British Journal of Cancer website (http://www.nature.com/bjc) 